\title{
Toxicological

\section{Effects of agricultural pollution on water and subterranean soil of Bahokalat river of Iran with reference to heavy metals}

\author{
Shoja Arianmehr ${ }^{* *}$ and Gholamsarvar Nouti-Zahi \\ ${ }^{1}$ Department of Water Engineering, Islamic Azad University, Khash Branch, Khash, Iran \\ ${ }^{2}$ Civil Engineering, First Deputy of Commercial, Industry, Mine and Agriculture Commission, Iran
}

\begin{abstract}
The universal growth of the population and the daily growing need for food caused the agriculture to improve more than ever, and more lands goes under cultivation every year. Different procedures have been applied to cultivate more products from one unit of an agricultural land, such as using different chemical substances like chemical fertilizers, weed fighters and insect killers. Applying such materials in agriculture causes pollution in surface and subterranean waters, hence for controlling the pollution we should have exact information about the amount of the dopants, specially heavy metals in aquatic and soil environments. In this research while taking samples of Bahokalat river waters in six stations, as well as taking samples from agricultural soils randomly in three stations, the density of heavy elements have been measured by atomic absorption machine. One-sided variance analyze test has been applied to compare the average of the heavy metals in the mentioned stations.
\end{abstract}

KEY WORDS: HEAVY METALS, CHEMICAL FERTILIZERS, WEED KILLERS, SURFACE \& SUBTERRANEAN WATERS, AGRICULTURAL WATERS

\section{INTRODUCTION}

The achieved results showed that the average amount of all parameters belonging to water quality resides within the admissible limits of drinking water and the amount of the lead in three stations of agricultural soils are more than the admissible rate. The amount of the copper in the agricultural soil species is more than the admissible rate.
The amount of the cadmium and zinc in the agricultural soil resides within the admissible limits. But measuring the level of the dopants in this environment is necessary considering the limitations of water and soil resources in the Province and regarding that the drinking water of the area is supplied by this reservoir (Hashemi, 2010).

As the population of the world grows more pressures exert on all principal resources that somehow play a

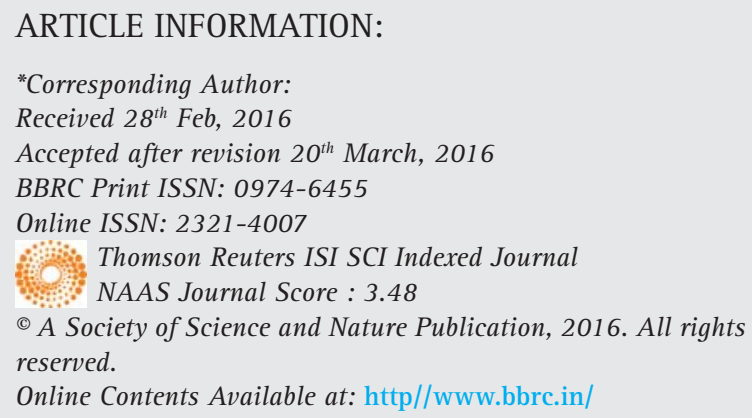


fundamental role in the production of foods. Statistics and information's shows that more than 99\% of foods in the world is supplied by agricultural fields, and less than one remaining percent is supplied by oceans and other aqua settlements (Salari, 2010). a salient growth have been seen in the food production in the recent decades applying chemical fertilizers, weed killers, plague removers, disinfectants, and expanding agricultural lands almost all the surface waters have a high range of pollution, industrially or naturally originated, by their flow in urban and industrial regions that makes the water inconsumable for drinking water (El-Jaouala). Ecologically, dopants are of two kinds: construable dopants and unconstruable dopants. The uncostruable dopants such as heavy metal and phosphate compositions, Fennel chemical compositions with long continuum that accumulates in the environment and effects the food and biological continuum which exist in the water (Schilcher, 1983), Actually heavy metals do not eject from the body after entering it, but it sediments and accumulates in tissues such as fats, muscles, bones, and junctures which leads to manifold disease and complications. Generally nervous disorders like Parkinsons, Alzheimers, depression, Skizophrenia and some cancers, nutrition destitution, disbandment of hormones and others results from the over exposure of heavy metals to human body, (Boustanian, 2011 and Rajaei et al., 2012).

In studies done on the Northeast River in Maryland state of America, which has been one of the most problematic rivers as it contains inordinate amounts of nutrients such as nitrogen and phosphate, eutrophication was the most common feature observed. In a research done to survey the amount of the heavy metals in agricultural soil and irrigated waters by urban sewage, the present results show that irrigating the agricultural soils by Zabol city sewage causes the accumulation of heavy metals in soil and plant, therewith increasing the bacterial load.

Rajei et al., (2012) studying the density of the heavy metals in water reservoirs of half of Sistan province showed that the average densities of chromium, cadmium, nickel, and lead are far more than the standards of the world manuals of hygiene.

The results achieved by measuring some parameters of water quality and heavy metal density in water reservoirs of Sistan and Balochestan Province show that the density of iron and manganese are more than the maximum admissible level. Researches done about the effect of agriculture on pollution of the northeast river of Maryland state showed that straight evacuation of chemical fertilizers and weed killers in river waters are the principal factors of surface water pollutions. Studying the density of heavy metals in drinking water of different regions of Tehran also showed that the amount of density of lead in some points is more than the standard levels of Department of Environment.

Research on the quality of subterranean waters of Bahar Champaign of Hamedan indicated that in current situations no danger fall on the subterranean waters of the Champaign. Considering the probability of pollution outspread to the river caused by developing agriculture activities within the irrigation and drainage and sewage net of human sources because of mild growth of villages, and regarding that the water of this river is used for drinking of the area dwellers beside the agricultural activities, the highness of the density of these elements forms a threat on the water consumers. Kowsar and Ahmad (2012) studied the pollution of the subterranean water sources in Kahota industry of Islam Abad, Pakistan and the results showed that pollutions such selenium exists in water of the area, which has also been shown by Rajaei et al., (2012).

In this research of case study, the role of agricultural activities in polluting the water sources (surface and subterranean) and the amount of heavy metals in water and soil have been surveyed and discussed, and then different solutions have been proposed to optimize the consumption of water, the staff of life, and in this way to help reducing the water crisis.

\section{MATERIAL AND METHODS}

Bahokalat river is one of the most watery rivers in Sistan and Balochestan province and is the principal factor of life and existence in southern Balochestan. This river collects a vast area of south plate of Iranshahr city (Sarbaz, Bampour, Rask districts) and Chabahar city (Dashtiary, and Ghasr-e-Ghand districts) and recline them to Oman sea. Bahokalat river originates from Pirabad mountains which is located $47 \mathrm{kms}$ from southeast of Iranshahr and $38 \mathrm{~km}$ northwest of Sarbaz. This river has a tourist importance since it is also a settlement of Iranian crocodile (Rajaei, et al., 2010).

Taking samples from the river has been done in six times in 2015. Three times of the sampling was done when the river had more water and three other samplings were when it had less water. Problems concerning eutrophication occured more in summer times since the low level of the river, sunshine, and the moderate temperature, all together created ideal circumstances for growing of aquatic plants and annihilation of dead plant remnants, which causes unfair and critical circumstances for the river in summer. First stage: the first level of sampling of the river has been done according to standard methods. To achieve exact information from all river, surface water sampling has been done from all reservoir surface using the universal position finding system (GPS). 
For this purpose, sampling has been done in 6 stations and for each station in two depths (surface and bed). The water sampling containers are of poly ethylene that has been washed by nitric acid 5\%, and then washed by Aquapura and dried. Immediately after sampling water quality parameters such as temperature, electric conductivity, all illiquid ingredients and $\mathrm{PH}$ have been measured by thermometer, Ecometer, and $\mathrm{Ph}$ meter that has been calibrated by standard solutions, and wrote in. For surface sampling the samples have been taken from $20 \mathrm{~cm}$ of the surface, and from the bed of the reservoir sample have been taken by Rotner sampling machine. After filling the sample bottle, the $\mathrm{PH}$ has been reached 2 using Nitric Acid 65\% and transferred to laboratory adjacent to ice. For the sample water to be digested the amount of $50 \mathrm{ml}$. of it has been combined with dense Nitric Acid (5 Mi.), then heated in a gravel bath to 90 dc. . in order to reach the volume of $10 \mathrm{ml}$.. Finally after cooling the composition, it will be filtered and extended to the wanted volume. After that, the density of the metals will be measured by ICP-OES machine. For accuracy of the measurement the machine has measured the density in three repetitions that this accuracy means 90-95\% accurate. For determining correlation coefficient of the heavy metals the SPSS 16 software has been applied.

Second stage: this stage has been done for the purpose of surveying the amount of heavy metals such as lead, zinc, copper, and cadmium in the agricultural soil samples in the chosen stations. The soil samples have been taken from 0 to $20 \mathrm{~cm}$ depth of the earth. The sampling container is of poly ethylene that has been washed by washing powder and kept in Nitric acid 5\% for a limited time. Then, washed by ionized water and closed. The soil samples have been put for 24 hours in oven in 70 c heat to be dried after being transferred to laboratory. In the next step, the soil have been sifted and grinded to get a monotonic powder. $0 / 5$ gr. Of the above sample will be prepared for injection to the machine by the total digestion method. For measuring all ingredients existing in this research the atomic attraction flame method. For achieving the desired sensitivity in these measurements air-stilling flame has been applied. The measurements have been repeated three times and standard deviation and data averages have been achieved. For comparing the heavy metal average in chosen samples of the three regions one-sided variance analyze test has been applied.

\section{RESULTS AND DISCUSSION}

The results of the statistical analysis of the heavy metal samples from the river as well as statistical parameters (average, minimum, maximum, standard deviation, var- iation coefficient) are shown in table 1 on this basis the density of heavy metals in Bahokalat river is as follow:

\section{HEAVY METALS IN THE RIVER}

The results show that the average of Arsenic density in the river is $0 / 0062$ micrograms per liter that is less than the standards of world hygiene organization and the national standards.

Studies of Gunduz et al., (2010) measured the arsenide pollution in Dasht-e-Sima, Turkey and its effects on human health, they showed 99/1 of arsenic density and its maximum was 56115 micrograms per liter, which is much more higher than the arsenic density found presently in the river. The results of cadmium density showed that the average density of this metal in the river in surface sampling was $0.0069 \mathrm{mg} / \mathrm{l}$ and in reservoir bed was $0.032 \mathrm{mg} / \mathrm{l}$, that considering the admissible maximum of 0.003 milligrams per liter the amount of cadmium in river is within the admissible limits. The consumption of cadmium in agricultural activities (chemical toxicants or phosphate fertilizers) is indicated a source of interring of cadmium into the environment, hence probably human activities (agricultural and human sewage) is one of effective reasons on the cadmium density therewith geological specifications.

The results of nickel density in the river showed that the change amplitude of nickel is between 0.016-0.021 micrograms that is under the standard admissible limit. The densities of nickel in environment is caused by fussily fuels which come out of powerhouses, mines, refineries, over plus burnings, and hospital slopes. Considering that above parameters do not exist in the region, so there is probability that the density of nickel in the water relates to geological specifications of the region. Nickel is one of the heavy metals that have the most mobility and trans ability in aqua environments. Soluble compositions in water such as chloride nickel, sulphate nickel, and nitrate nickel are surveyable compositions hygienically. In a research done on Gavkhooni lagoon the average density of nickel was 480 micrograms per liter that was much higher than its density in the river. The results of average density of copper and iron in the river was 0.016 and 0.349 micrograms per liter that is under the admissible limit and does not create any problem for water consumers.in the current study the density of these metals obtained are under the national standard. For copper the average density in the river in surface and bed samples are 0.016 and 0.019 per liter respectively.

Considering the desired and admissible amount in the water the density of this metal in the river is within the desired limits. So it does not make any restriction for water consumers of this river. Insomuch the standard 


\begin{tabular}{|c|c|c|c|c|c|c|c|c|c|}
\hline $\begin{array}{l}\text { Station } \\
\text { No }\end{array}$ & $\begin{array}{l}\text { Place of } \\
\text { sample }\end{array}$ & $\begin{array}{l}\text { Depth of } \\
\text { sample } \\
\text { (metre) }\end{array}$ & $\begin{array}{l}\mathrm{Cr} \\
\text { (mg/litre) }\end{array}$ & $\begin{array}{l}\mathrm{Cd} \\
\text { (mg/litre) }\end{array}$ & $\begin{array}{l}\text { As } \\
\text { (mg/litre) }\end{array}$ & $\begin{array}{l}\mathrm{Cu} \\
\text { (mg/litre) }\end{array}$ & $\begin{array}{l}\mathrm{Ni} \\
\text { (mg/litre) }\end{array}$ & $\begin{array}{l}\text { Mn } \\
\text { (mg/litre) }\end{array}$ & $\begin{array}{l}\mathrm{Fe} \\
\text { (mg/litre) }\end{array}$ \\
\hline \multirow[t]{2}{*}{1} & $\begin{array}{l}\text { Surface } \\
\text { sample }\end{array}$ & 0.2 & 0.67 & 0.003 & 0.0034 & 0.024 & 0.030 & 0.51 & 0.324 \\
\hline & Bed sample & 18.7 & 0.019 & 0.0054 & 0.0072 & 0.045 & 0.059 & 0.13 & 0.459 \\
\hline \multirow[t]{2}{*}{2} & $\begin{array}{l}\text { Surface } \\
\text { sample }\end{array}$ & 0.2 & 0.529 & 0.0066 & 0.0035 & 0.0063 & 0.0071 & 0.412 & 0.363 \\
\hline & Bed sample & 6.4 & 0.401 & 0.0079 & 0.0082 & 0.0051 & 0.0069 & 0.501 & 0.386 \\
\hline \multirow[t]{2}{*}{3} & $\begin{array}{l}\text { Surface } \\
\text { sample }\end{array}$ & 0.2 & 0.259 & 0.0082 & 0.0065 & 0.0118 & 0.0119 & 0.327 & 0.369 \\
\hline & Bed sample & 10 & 0.368 & 0.098 & 0.038 & 0.0254 & 0.0321 & 0.489 & 0.472 \\
\hline \multirow[t]{2}{*}{4} & $\begin{array}{l}\text { Surface } \\
\text { sample }\end{array}$ & 0.2 & 0.423 & 0.0045 & 0.0059 & 0.017 & 0.011 & 0.574 & 0.319 \\
\hline & Bed sample & 7.5 & 0.291 & 0.0049 & 0.0033 & 0.0219 & 0.0159 & 0.609 & 0.391 \\
\hline \multirow[t]{2}{*}{5} & $\begin{array}{l}\text { Surface } \\
\text { sample }\end{array}$ & 0.2 & 0.259 & 0.0126 & 0.0136 & 0.0051 & 0.0074 & 0.445 & 0.353 \\
\hline & Bed sample & 13.2 & 0.398 & 0.074 & 0.039 & 0.00102 & 0.00114 & 0.572 & 0.498 \\
\hline \multirow[t]{2}{*}{6} & $\begin{array}{l}\text { Surface } \\
\text { sample }\end{array}$ & 0.2 & 0.265 & 0.0066 & 0.0044 & 0.0318 & 0.0301 & 0.459 & 0.366 \\
\hline & Bed sample & 9.1 & 0.264 & 0.0051 & 0.0032 & 0.0202 & 0.0145 & 0.61 & 0.374 \\
\hline \multirow[t]{2}{*}{ Average } & $\begin{array}{l}\text { Surface } \\
\text { sample }\end{array}$ & 0.2 & 0.4 & 0.0069 & 0.0062 & 0.016 & 0.016 & 0.454 & 0.349 \\
\hline & Bed sample & 10.81 & 0.29 & 0.032 & 0.016 & 0.019 & 0.021 & 0.485 & 0.43 \\
\hline \multirow[t]{2}{*}{$\begin{array}{l}\text { Maximum } \\
\text { amount }\end{array}$} & $\begin{array}{l}\text { Surface } \\
\text { sample }\end{array}$ & 0.2 & 0.67 & 0.0126 & 0.0065 & 0.0318 & 0.0301 & 0.574 & 0.369 \\
\hline & Bed sample & 18.7 & 0.401 & 0.098 & 0.039 & 0.045 & 0.059 & 0.61 & 0.498 \\
\hline \multirow[t]{2}{*}{$\begin{array}{l}\text { Minimum } \\
\text { amount }\end{array}$} & $\begin{array}{l}\text { Surface } \\
\text { sample }\end{array}$ & 0.2 & 0.259 & 0.003 & 0.0034 & 0.0051 & 0.0071 & 0.327 & 0.319 \\
\hline & Bed sample & 6.4 & 0.019 & 0.0049 & 0.0032 & 0.00102 & 0.00114 & 0.13 & 0.374 \\
\hline \multirow[t]{2}{*}{$\begin{array}{l}\text { Deviation } \\
\text { coefficient }\end{array}$} & $\begin{array}{l}\text { Surface } \\
\text { sample }\end{array}$ & 0 & 0.58 & 0.75 & 0.96 & 0.86 & 0.36 & 0.52 & 0.42 \\
\hline & Bed sample & $3 / 4$ & 0.42 & 0.51 & 0.74 & 0.65 & 0.49 & 0.65 & 0.39 \\
\hline
\end{tabular}

amount of iron in drink water its desired maximum is equal to 0.3 and maximum admissible amount is 1 milligrams, the average amount of iron density in water obtained was 0.349 milligrams that is a little more than the desired amount in drink water but less than the admissible amount, hereon no pollutions found about this metal. Chrome is a poisonous element and its venenation depends upon its chemical formation, since a six-valent chrome is more poisonous than threevalent chrome. Vital and unvital factors that causes sixvalent chrome to increase, may increase the degree of its venenation in water.it is probable that beside the geological specifications, one of the reasons why the density of chrome is high in the river is the agricultural activities around the river. The average density of the chrome in the river is 0.4 and 0.29 micrograms per liter that is under the standard limit and makes no problem for the consumers. The national standard and world hygiene organization standard announced the maximum acceptable amount of chrome in drinking water equal to 50 micrograms per liter. Order of heavy metal density found in the river is as follows:

$$
\mathrm{Cr}>\mathrm{Mn}>\mathrm{Fe}>\mathrm{Ni}>\mathrm{Cu}>\mathrm{As}>\mathrm{Cd}
$$

The desired and admissible maximum of manganese in drinking water is equal to 0.454 and 0.485 milligrams per liter. The average obtained in both surface and bed samples were less than the admissible maximum. The veneration of manganese essentially affects the aspiration system and brain. Specifically harms the nervous system and may cause Parkinson. The poisonous amount of manganese causes septum inflation in white parts of the leaf and also makes brown spots on the surface of the leaf, although there is a little distance between manganese shortage and amount that causes veneration in the plant.The reason why manganese density increases 


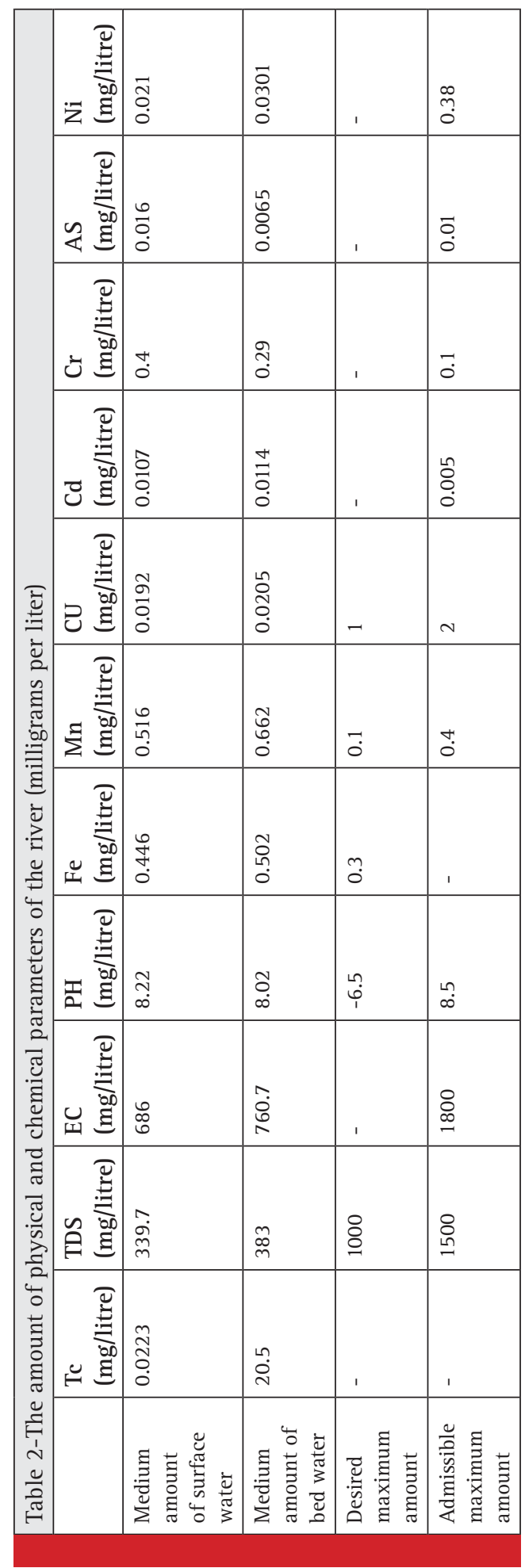

in water samples in comparison to other metals is its high solubility in water.

To specify the quality level and heavy metal density concerning the obtained results from checked parameters of the river its averages has been compared with desired maximum standards and national admissible maximum standards of Iran Industrial Researches Institute. The amount of these parameters is shown in table 2 .

\section{POLLUTION OF SUBTERRANEAN WATER}

An ample widespread of pollution that enters subterranean waters are chemical fertilizer residuum, weed fighters, insect killers, that consist of very poisonous and dangerous substances. Most of these fertilizers contain nitrogen that causes increase in nitrate density in water ( 9 within milligrams per liter).these compositions are high soluble, and due to nonsystematic irrigation methods and the high amount of these fertilizers, they are washed from the soil and enter the subterranean water sources and pollute them. The rate of the pollution depends upon the kind and amount of chemical substances, continental circumstances of the region, the rate of the rain (rain and snow), and the kind of the soil (gravel and sand have high absorbability). In samples taken from some wells in agricultural regions, the results showed that the pollution of these wells specially nitrate pollution was more than the admissible rate.

Table 3 shows that the lead rate and also the density of this substance in agricultural soil of all regions are higher than the admissible rate (10 ppm). The reason of this matter is theunmonotonic use of slop in irrigating cultivated farms, since in the time of high level of water in the river the irrigation is done by the water of the river that in turn superficially washes the heavy metals from the surface of the soil. Since the maximum penetrance depth of heavy metals are at $15 \mathrm{~cm}$. of the surface soil. Statistical analysis has been done using SPSS17 software and one-sided variance analyze test. The achieved results by the tests showed that in certain level of 95\% and meaningful level less than $0 / 05(\mathrm{P} 7.13>4.1)$ there is a meaningful difference between the averages of lead density in the chosen areas. Data in table 3 show that the cadmium amount in agricultural soil of mentioned areas is close to its admissible amount in soil (1.5-2 PPM).

The results of ANOVA test in certain level of 95\% and a meaningful level less than $0 / 05$ (P 8.53>4.1) show that the variance of averages in copper measurement in the mentioned stations are significant. Table 3 shows that all data related to zinc measurement indicate that zinc is within admissible rate in the mentioned areas. One-element variance analyze test in certain level of 95\% and meaningful level less than 0/05 (P 12.43>4.1) showed a significant difference in measuring zinc in the three areas. 
Table 3: The presence of heavy metals (ppm) in soil of three different stations

\begin{tabular}{|l|l|l|l|}
\hline Parameter & \multicolumn{3}{|l|}{ Density of heavy metals in agricultural soil } \\
\hline & Station 1 & Station 2 & Station 3 \\
\hline $\mathrm{CD}(\mathrm{mg} /$ litre $)$ & $38.43+0.02$ & $36.87+0.01$ & $33.62+0.02$ \\
\hline $\mathrm{Cu}(\mathrm{mg} /$ litre $)$ & $1.02+0.01$ & $0.95+0.01$ & $0.92+0.01$ \\
\hline $\mathrm{Pb}(\mathrm{mg} /$ litre) & $30.43+0.01$ & $28.86+0.7$ & $25.78+0.03$ \\
\hline $\mathrm{Zn}(\mathrm{mg} /$ litre) & $120.26+0.2$ & $123.41+0.1$ & $121.32+0.05$ \\
\hline
\end{tabular}

The results of above survey shows that although in limited periods of year when water is flowing in Bahokalat river and farms are being irrigated with agricultural water, but the repeated use of sewage due to continual shortage of agricultural water causes bacterization in farms and accumulation of heavy metals in soil. Resistance and constancy of heavy metals in soil is more prolix in comparison to other dopants and the soil pollution by heavy metals is permanent. Nowadays the pollution of soil and water by heavy metals are returned to environmental crisis worry due to its potential harmful ecological effects. These data are in corroboration with those of earlier studies of ElJaouala and Cox (2008) Hashemi et al., 2010 Gunduz et al., 2010, and Rajaei et al., 2012).

Measured parameters in river reservoirs lie in admissible limits of drinking water that indicates the desired quality of drinking water of the reservoirs, although it is suggested to do more studies on heavy metals that exist in water and river dregs. Pierson correlation coefficient has been done on the data achieved from three repetitions averages in the studied stations. According to the mentioned table there is a relatively high correlation between cadmium density and other metals (exception: copper and iron).

\section{SOLUTIONS TO PREVENT POLLUTION IN SURFACE AND SUBTERRANEAN WATERS}

Guarding and continual measuring of heavy metal rates in agricultural water and soil samples.Developing a sewage refinery in the area, cleaning up the slop totally considering the famine in areas which needs irrigation.

Amending the irrigation methods is one of the points that must be considered. It is suggested to use urea with sulfur cover to hinder urea washing, and to increase the operation and decrease of nitrate in subterranean waters to prevent nitrogen density increase in form of nitrate in running and subterranean waters. This method is rec- ommended specially for cultivations such as rice which needs water greatly and in high range of raining too.

Applying ammonium sulfate instead of urea (because of superficial absorbability of cation ammonium for major of cultivations.

Fertilizing of nitrogen fertilizers in several stages, especially in light soils.

Trying to store nitrate of the soil as organic sources through more use of animal and green fertilizers.

\section{REFERENCES}

Boustanian M. (2011). Removal of Cadmium from aqueous solution by windy sand in Sistan plain. M.Sc. Thesis. Zabol University, 159p. (In Persian)

El-Jaouala T., and Cox, D.A. (2008). Manganese toxicity in plants. J. Plant Nutr.21: 353-386.

Gunduz 0., Celalettin Simsek and Altug Hasozbek (2010) Arsenic Pollution in the Groundwater of Simav Plain,Turkey: Its Impact on Water Quality and Human Health Water Air Soil Pollut 205:43-62

Hashemi E., Mousavi F., Taheri M., and Ghareh-Chahi A. (2010). Analysis of Groundwater Quality Acceptability for Drinking purposes in Nine Cities in Isfahan Province Using Fuzzy Inference System. Iran-Water Resources Research. 6(3); 25-34. (In Persian)

Kousar R. and S. Ahmad (2012) Pollution status of Industries of Islamabad,12th National and 3rd International Conference of Botany Islamabad Pakistan

Rajaei Q., Jahantigh H., Mir A., Hesari Motlagh S. and Hasanpour M. (2012). Evaluation of Concentration of Heavy Metals in Chahnimeh Water Reservoirs of Sistan-va-Baloochestan Province in 2010. J.Mazand Univ.Sci. 22: 105-112. (In Persian)

Salari-Bardsiri M. (2010). Examination of Adsorption Isotherm Models of Ni(II) ions by Activated Carbon and Pistachio Shells within Equilibrium Time. M.Sc.Thesis. Zabol University, 155p. (In Persian)

Schilcher H. (1983). Contamination of natural products with pesticides and heavy metals. Amsterdam: Elsevier Science Publishers 417-423. 